\title{
Social Status of Elderly People in Health Perspective: A Comparison of Rural and Urban Area
}

\author{
Mirza Amirun Nesa ${ }^{1}$, Md. Emdadul Haque ${ }^{2}$, Dr. N. M. R. Siddiqua ${ }^{3}$ and \\ M. Imdadul Haque ${ }^{4}$ \\ ${ }^{I}$ Lecturer, Department of Sociology, Begum Rokeya University, Rangpur, Bangladesh \\ ${ }^{2}$ Lecturer, Department of Disaster Management, Begum Rokeya University, Rangpur, Bangladesh \\ ${ }^{3}$ Assistant Registrar, Department of Gynae \& Obs, Rangpur Medical College Hospital, Rangpur, Bangladesh \\ ${ }^{4}$ Professor, Department of Sociology, University of Dhaka, Bangladesh
}

\begin{abstract}
Ageing is natural and inevitable consequence of human life. Once born, there is no scope for man from old age. Old age bring both physical ailments and social problems. Major social problem of the old people is their adjustment to their surrounding social world in general and their immediate families in particular. Old people very often feel neglected and forgotten. This gives rise to anger, sorrows and frustration leading to tension in the family. This study was undertaken to understand the health status of elderly people and to gather some information about their perceived health needs using the information over Thakurgoan district. The study has covered both quantitative and qualitative information. Necessary data were collected through interviews and intensive observation, questionnaire and the case study techniques were used with one assumption that these will provide a better insight into the experience of care giving and care receiving processes than a survey alone could do. Herein, an attempt is made to describe the situation and major health problems faced by the elderly from 80 (20 men 20 women) elderly population of aged 60 and above in one urban and one rural communities of Thakurgoan. The survey findings indicate that elderly men and women lack access to land and agricultural resources. Access to resources, and therefore livelihood strategies, have changed for both older men and women. Most of the elderly populations are landless and they earn very little from land. The findings from the study show that poor older people in rural areas faces very difficult circumstances as they attempt to meet their basic needs. Many elderly persons have only homestead land but no agricultural land. The health status of elderly population is poor and they lack access to basic health care. About 80 percent of the elderly population suffered from health problems. Almost every one suffered from at least one disease during three months prior to the survey. The average duration of suffering from diseases ranged from 3 years to 9 years. The vibration analysis shows that age, sex, access to treatment and income is associated with the health problems of the older population.
\end{abstract}

Keywords: Elderly, Quantitative, Qualitative, Treatment and Ailments.

\section{Introduction}

Ageing is natural and inevitable consequence of human life. Once born, there is no scope for man from old age. Old age bring both physical ailments and social problems. Major social problem of the old people is their adjustment to their surrounding social world in general and their immediate families in particular. In preindustrialized era, old peoples were taken care of in a joint family structure. In the sub-continental societies, old peoples were used to get honor and reverence from the society at large. And their family treated them humanely and with care and sympathy. Advent of industrialization and urbanization has drastically changed social and familial life. The joint family has disappeared people in the society are becoming more and more individualistic. In this situation, the old people are facing the problem of adjustment to their families. Old people very often feel neglected and forgotten. This gives rise to anger, sorrows and frustration leading to tension in the family. The problem has already become public in the west. It is also on its way become so in Bangladesh.

In the past, joint family was the common pattern that existed with the head of the family enjoying sights, responsibilities, commanding obedience, and respect from other member of the family. It exists in rural areas, provides the necessary care to the aged in many families. Under the impact of industrialization and urbanization the traditional joint family system is becoming more precarious. Apart from facing specific difficulties like scarce accommodation high cost of living and expensive medical care, many elderly people also await the grim prospect of being unloved and becoming unwanted.

Rao et al., (2003) in a study of health status of the rural aged in Andhra Pradesh, found that health problems tend to increase with advancing age and very often the problems aggravate due to neglect, poor economic status, social deprivation and inappropriate dietary intake. A high proportion of the total respondents 
stated that they were suffering from illness seriously. Lack of medical facilities in the village and poor economic conditions might be responsible for the low health status of the villagers (Rao et al.,2003). This is corroborate by the finding of Singh et. al. (2005) in his study in rural Haryana. Hence, majority of landless rural aged were suffering from one or the other health problems and physical disabilities. Achir (1998), in the paper "Strategies to formulate Family Support System and Community based services for the care of the old" showed although, changes are good indicators of development, dilemma for support capacity of the family towards the elderly is inevitable. With many women entering the work force, available support for the elderly has significantly reduced. As a consequence, the International Year of the Family has appealed to the world to maintain, strengthen and protect the family to ensure continuity of its vital role in preserving dignity, status and security of its ageing members. Pappathi et al. (2005) In the Paper "Psycho-social characteristics and problems of Rural Aged" showed that the psycho-social perspectives and problems and strategies to welfare of the rural female aged found that a majority suffer from joint pain, blood pressure and chest pain. A few complaint of asthma, piles, lose of weight, diabetes and skin diseases. Only 30 per cent among the rural aged where in good health. Vasantha (1998), In the Paper "Nutrition and Health Problems" found that the rural aged suffered from nutritional, psychological and other problems, when compare to urban aged. The aged employed privately and those self employed had more of health problems then not gainfully employed person. In general, the male members were found to be literate, economically independent and had less physiological and nutritional problem when compare to the female counter parts, when literacy level, income level and employment status improve, they seem to have better health. Nair (1989), a study on "The Aged in Rural India: A study of the Socio-Economic and Health Profile", revealed that the incident and prevalence of chronic as well as nonchronic disease are more in rural elderly that is 1) respiratory diseases, 2) loco-motor illnesses and 3) blood pressure. The majority of the aged comparatively longer among males. J. Balamurugan and G. Ramathirtham (2012) observed that the number and types of variable and their extent of influence on the health status (both perceived and actual) of the elderly vary. Further, these are certain common specific factors that influence the health status among the elderly belonging to gender wise distribution. Hence, these findings raise a number of issues for formulating appropriate health policies for the elderly. Similarly, the pattern of various inputs for developing the appropriate social policy for the welfare of the elderly may also have to be suitably modified in view of the living conditions of the elderly. Relatively few study has focused on the epidemiology and health situation of elderly in Bangladesh. Perhaps the oldest study conducted by Ibrahim (1981) in his unpublished paper entitled "Problems of the Aged in Bangladesh" presented at the "Symposium on Population Development and Social Security: Ageing in Developing Countries, Hamburg, Federal republic of Germany" documented the health and socio-economic problems of older persons. Mostafa and Streatfield (2002) in their study found that poor elderly largely attribute their health problems, on the basis of easily indefinable symptoms, like chest pain, shortness of breath, prolonged cough, breathlessness, asthma and so on. Mental health is also found to be another important health issue among rural elderly. A study was conducted by Kalam and Khan (2006). This paper attempts to explore the types of illness among older people in Bangladesh using data collected from a national survey. It also describes the factors associated with health situation of the elderly in Bangladesh.

Wrosch C. et. al.(2007) in their paper suggest that adaptive levels of Health Engagement Control Strategies(HECS) represent a psychological mechanism that can protect older adults from experiencing the adverse emotional and biological consequences of physical health problems.

The major objectives of this study are

To look into the problems of the elderly people in urban and rural by socio-economic and cultural view in Bangladesh

To study the formal and informal health care systems of elderly people

To make some ideas so that on the basis of these ideas applying in them

\section{Materials And Methods}

\subsection{Study area}

The study was conducted into two areas. One is rural area and another is urban area for the comparative analysis of the elderly people's back grounds. The urban area is located at Thakurgaon Pourasobha which is 88.44 East to 88.48 East and 26,03 North to 26.02 North, where as the rural area is located at 88.51 East to 88.62 East and 26.14 North to 26.12 under Thakurgaon district. These areas were selected for the study because the researcher was rapport with them before. 


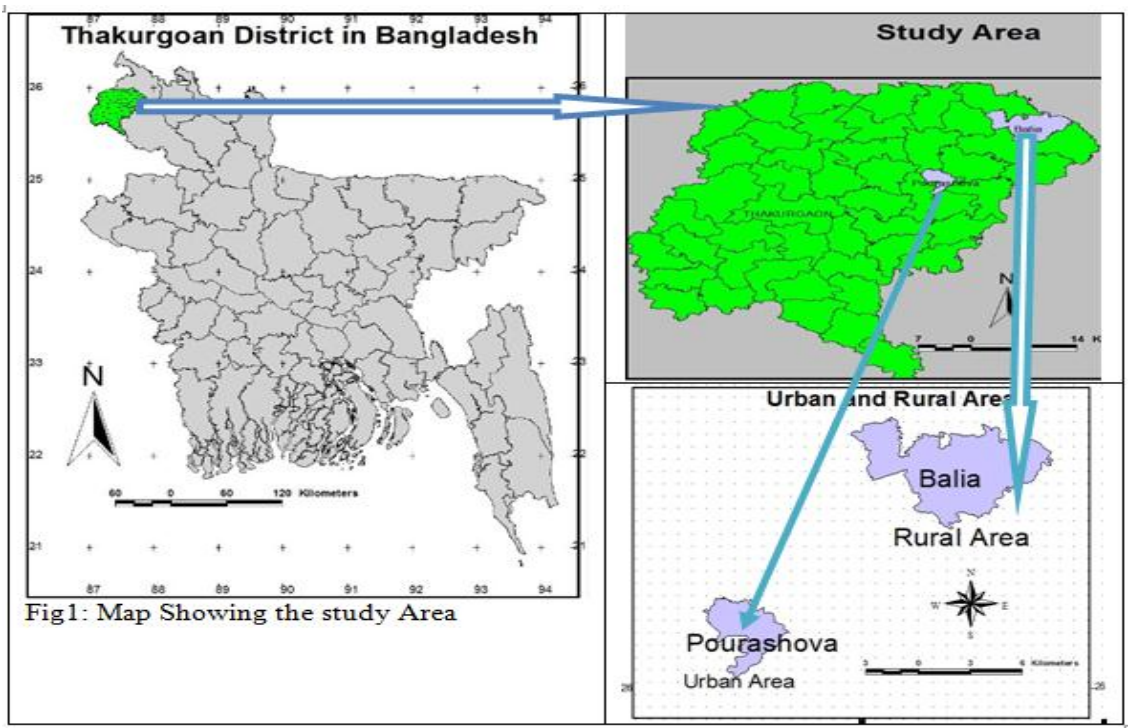

\subsection{Methodology}

The study has covered both quantitative and qualitative information. Necessary data were collected through interviews and intensive observation, questionnaire and the case study techniques were used with one assumption that these will provide a better insight into the experience of care giving and care receiving processes than a survey alone could do.

\subsection{Sampling}

For the purpose of this study a rural village and an urban were purposively used. From the selected areas equal number of elderly men and women were selected (20 men 20 women) from each area. The total number of sample respondents were 80 .

\subsection{Data collection techniques}

Data were collected for this study was from 80 elderly (aged 60 years and above) men and women from urban and rural areas. For this study structured questionnaire was used.

\subsection{Data analysis}

The collected data from the field were edited properly and made them into classification and tabulation according to their characteristics. The sata were processed using different statistical methods. For the purpose of processing of data relevant statistical data were followed. The results were presented by bar diagrams.

\section{Results And Discussion}

\subsection{Data analysis and presentation socio-economic background of the older population}

Socio-economic background of the respondents was studied to understand the situation of elderly population. The sample respondent were classified by sex and by place of residence Table shows the selected socio-economic characters of the older population from both urban and rural areas. The study is also considered some selected demographic characteristics of the sample elderly population such as age, mental status, family type, and dependency status in the household. The information is shown in table 1.

TABLE 1: Description of sample by residence.

\begin{tabular}{|l|l|l|}
\hline Indicator & Rural $(\mathbf{M + F}) \mathbf{= 4 0}(\boldsymbol{\%})$ & Urban $(\mathbf{M + F})=\mathbf{4 0}(\boldsymbol{\%})$ \\
\hline Sex & & \\
Women & 50 & 50 \\
Men & 50 & 50 \\
Age 60-64 years & 40 & 50 \\
65-69 years & 30 & 20 \\
70-74 years & 15 & 15 \\
>75 years & 15 & 15 \\
Literacy Level: & & \\
Illiterate & 75 & 70 \\
Literate & 25 & 30 \\
Average family Income & $1,049.83$ & $3,099.58$ \\
Women & 999.86 & $2,299.65$ \\
Men & & \\
\hline
\end{tabular}




\subsection{Family type}

Bangladeshi society has been experiencing rapid changes in household size and compositional relationship within and between household members of different generations. Religious and cultural traditions have resulted in a strong extended family system upon which older people have traditionally relied for survival (Samad, 1998). Traditionally old people depend on their adult children, particularly sons, for old age support and security. Increased migration of the work force changing in the family structure and trends toward smaller family size and other socio-economic changes may adverse affect the old age support system in the society. One important concern of the elderly population is the breaking of traditional joint family system. However, this is not reflected from the present survey. It seems that in the present survey elderly men and women both came from nuclear and joint families. The information collected shows that about $40 \%$ of the respondents from both urban and rural areas came from nuclear family. Over $45 \%$ of the respondents were from joint family in rural areas as opposed to about 50\% from urban areas. In urban areas because of problems of living space there is a trend that all the family members stay together. The data also show that about $40 \%$ of the respondents in rural areas were from extended family. The comparable figure in urban area was about $20 \%$. The trend found on the family structure is not common now in Bangladesh. However, with modernization, a decrease in land availability, an increase in women's participation in the labor market, children migrating to urban areas, and the overall impact of pervasive poverty, it is generally acknowledged that this traditional form of support for the elderly population is weakening. There are evidences of breaking of joint family and formation nuclear family. If this continues then this would imply that family support for the elderly population will decline in future.

\subsection{Age Distribution}

Age distribution of the respondents by sex and by place of residence shows that from the rural areas about $40 \%$ and $40 \%$ older men and women aged 60-64 years were interviewed. The comparable figure in the urban areas was higher for males $50 \%$ but females were the same proportions $(45 \%)$ similar to rural older women. As expected relatively older women aged 85 years and above were interviewed from both areas than the older men. The mean age of the respondents by sex and by place of residence with same with over 67 years Table 2.

TABLE 2: Socio-economic and Demographic Characteristics of the Respondents.

\begin{tabular}{|l|l|l|l|l|}
\hline Age of respondent & $\begin{array}{l}\text { Rural males (\%) } \\
\mathrm{N}=20\end{array}$ & $\begin{array}{l}\text { Rural } \\
\text { Females } \\
\mathrm{N}=20\end{array}$ & $\begin{array}{l}\text { Urban } \\
\text { males }(\%) \\
\mathrm{N}=20\end{array}$ & $\begin{array}{l}\text { Urban } \\
(\%) \\
\mathrm{N}=20\end{array}$ \\
\hline $60-64$ & 40 & 40 & 50 & 45 \\
\hline $65-69$ & 30 & 30 & 20 & 25 \\
\hline $70-74$ & 15 & 15 & 15 & 15 \\
\hline $75-79$ & 5 & 5 & 5 & 5 \\
\hline $80-84$ & 5 & 5 & 5 & 5 \\
\hline $85+$ & 5 & 5 & 5 & 5 \\
\hline Mean age (in years) & 67.5 & 67.5 & 67.5 & 67.5 \\
\hline
\end{tabular}

\subsection{Marital Status}

Marital Status of the elderly sample respondents was also collected and is shown in Figure 2 and Figure 2. More elderly women were widowed than elderly men. In rural area about $85 \%$ of the elderly women interviewed were widowed as opposed to $80 \%$ in urban area. The high proportion of widowhood among the women also supported the joint family structure. The differential is due to difference in the age at first marriage of the husband and wife. Although in recent years the gap in age at first marriage has been declining but it was high (in the past the age difference was high as more than 10 years). This differential has caused more women to become widowed. This also suggests that more elderly women will be vulnerable and will remain alone. Loneliness is a major problem of the elderly population. It also indicates that no one will remain in the household to provide support and care to the half to the elderly men and women; and women remain more vulnerable than elderly men.

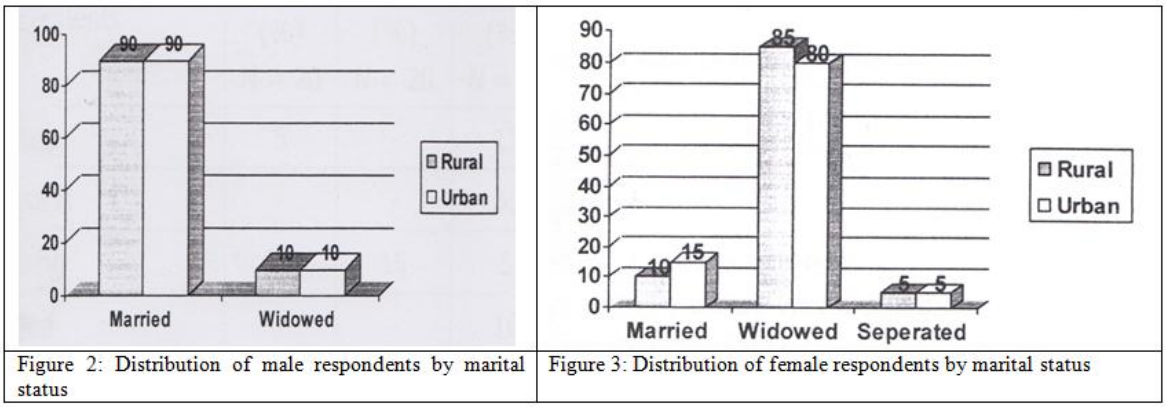




\subsection{OccupationPattern}

The occupational composition of the respondents suggests that majority of the male respondents about $50 \%$ had farming occupation, 5\% in services. The elderly females are mostly housewives (60\%), 10\% begging. In the urban areas 35\% involved in petty business, $15 \%$ services, $5 \%$ day labor/van driver. About $60 \%$ of urban female's occupation was housewife and $10 \%$ are in services Table 3 ..

TABLE 3: Occupation Pattern

\begin{tabular}{|l|l|l|l|l|}
\hline $\begin{array}{l}\text { Occupation of the } \\
\text { Respondents }\end{array}$ & $\begin{array}{l}\text { Rural males (\%) } \\
\mathrm{N}=20\end{array}$ & $\begin{array}{l}\text { Rural Females } \\
\mathrm{N}=20\end{array}$ & $\begin{array}{l}\text { Urban } \\
\text { males }(\%) \\
\mathrm{N}=20\end{array}$ & $\begin{array}{l}\text { Urban Females }(\%) \\
\mathrm{N}=20\end{array}$ \\
\hline Service & 5 & - & 15 & 10 \\
\hline Business & - & - & 35 & - \\
\hline Farming & 50 & 15 & 5 & - \\
\hline Retired & - & - & 10 & - \\
\hline Housewife & - & 60 & - & 60 \\
\hline Nothing & - & - & 15 & 15 \\
\hline Begging & 5 & 10 & - & 5 \\
\hline Day labor/van driver & 25 & 5 & 5 & - \\
\hline Others & 15 & 10 & 15 & 5 \\
\hline
\end{tabular}

\subsection{Education}

The level of education of the respondents shows that $55 \%$ of the elderly men were illiterate in rural area compared to $70 \%$ of the elderly women. Similarly about $45 \%$ of the elderly men were illiterate as opposed to $70 \%$ of the females in the urban area. In the rural area mean years of education for elderly men and women were 2.98 years and 1.83 years respectively. The comparable Table 4 for men and women in urban areas were 4.23 and 2.02 years respectively.

TABLE 4: Educations

\begin{tabular}{|l|l|l|l|l|}
\hline Level of Education & $\begin{array}{l}\text { Rural males (\%) } \\
\mathrm{N}=20\end{array}$ & $\begin{array}{l}\text { Rural Females } \\
\mathrm{N}=20\end{array}$ & $\begin{array}{l}\text { Urban } \\
\text { Males (\%) } \\
\mathrm{N}=20\end{array}$ & $\begin{array}{l}\text { Urban Females (\%) } \\
\mathrm{N}=20\end{array}$ \\
\hline No education & 55 & 70 & 45 & 70 \\
\hline 1-5 years & 20 & 15 & 20 & 10 \\
\hline 6-9 years & 15 & 10 & 15 & 15 \\
\hline 10 years and above & 10 & 5 & 20 & 5 \\
\hline Mean Years of Schooling & 2.98 & 1.83 & 4.23 & 2.02 \\
\hline
\end{tabular}

\subsection{Average Family Size}

Table 5 shows the average family size of the rural older males was higher by one person (6.7 persons against 5 persons) than the older women. The opposite is true in the urban area where average family size was higher for urban elderly females than the urban elderly males (4 persons against 3.5 persons).

TABLE 5: Family Sizes

\begin{tabular}{|l|l|l|l|l|}
\hline Family Size & $\begin{array}{l}\text { Rural males (\%) } \\
\mathrm{N}=20\end{array}$ & $\begin{array}{l}\text { Rural Females } \\
\mathrm{N}=20\end{array}$ & $\begin{array}{l}\text { Urban } \\
\text { Males (\%) } \\
\mathrm{N}=20\end{array}$ & $\begin{array}{l}\text { Urban Females (\%) } \\
\mathrm{N}=20\end{array}$ \\
\hline $\begin{array}{l}\text { Average family Size of the } \\
\text { respondents }\end{array}$ & 6.75 & 5 & 4 & 3.5 \\
\hline
\end{tabular}

\subsection{Family Income}

Family Income of the respondents was also collected and is presented. The mean monthly family income for rural males was Taka 1049.83. The comparable mean monthly family income of rural older women was Taka 999.86. In the urban area differential in family income was not much. The mean family income of the urban older men and women was Taka 3,099.58 and 2,299.65 respectively figure 4. 


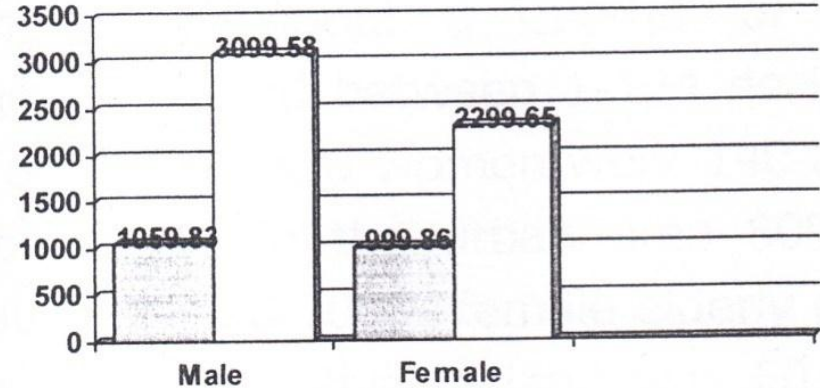

\section{口 Rural \\ 口Urban}

Figure 4: Distribution of Average Family Income by sex and place of residence

\subsection{Homestead Land}

In rural areas $5 \%$ older men and $20 \%$ older women had no homestead land, roughly three fourths of the respondents had between 1-29 decimal of land. In urban areas 15\% older men and 45\% older women had no land. In rural areas the average homestead land for older men and women were about 19 decimal and 15 decimal respectively as opposed to over 24.75 and 14.25 for older men and women respectively in the urban areas.

TABLE 6: Homestead Land

\begin{tabular}{|l|l|l|l|l|}
\hline Homestead land & $\begin{array}{l}\text { Rural males (\%) } \\
\mathrm{N}=20\end{array}$ & $\begin{array}{l}\text { Rural Females } \\
\mathrm{N}=20\end{array}$ & $\begin{array}{l}\text { Urban } \\
\text { Males (\%) } \\
\mathrm{N}=20\end{array}$ & $\begin{array}{l}\text { Urban Females (\%) } \\
\mathrm{N}=20\end{array}$ \\
\hline No land & 5 & 20 & 15 & 45 \\
\hline $1-29$ & 80 & 70 & 45 & 35 \\
\hline $30+$ & 15 & 10 & 40 & 20 \\
\hline Mean Land & 18.75 & 15 & 24.75 & 14.75 \\
\hline
\end{tabular}

\subsection{Cultivable Land}

The information on cultivable land shows that about $45 \%$ and $55 \%$ older men and women had o agricultural land respectively. About a quarter of the respondents had agricultural land between 1-124 decimal. The average land for older men and women were 140 decimal and 92 decimal respectively. In the urban area $80 \%$ of the male elderly population and $100 \%$ female elderly population had no land. The average cultivable land was 60 and 47 for rural older men and women respectively and non for urban older men and women respectively.

TABLE 7: Cultivable Land

\begin{tabular}{|l|l|l|l|l|}
\hline Cultivable land & $\begin{array}{l}\text { Rural males (\%) } \\
\mathrm{N}=20\end{array}$ & $\begin{array}{l}\text { Rural Females } \\
\mathrm{N}=20\end{array}$ & $\begin{array}{l}\text { Urban } \\
\text { Males (\%) } \\
\mathrm{N}=20\end{array}$ & $\begin{array}{l}\text { Urban Females (\%) } \\
\mathrm{N}=20\end{array}$ \\
\hline No land & 45 & 55 & 80 & 100 \\
\hline $1-124$ & 35 & 30 & 15 & - \\
\hline $125+$ & 20 & 15 & 5 & - \\
\hline Mean Land (in decimal) & 59.37 & 46.88 & 12.5 & 0.00 \\
\hline
\end{tabular}

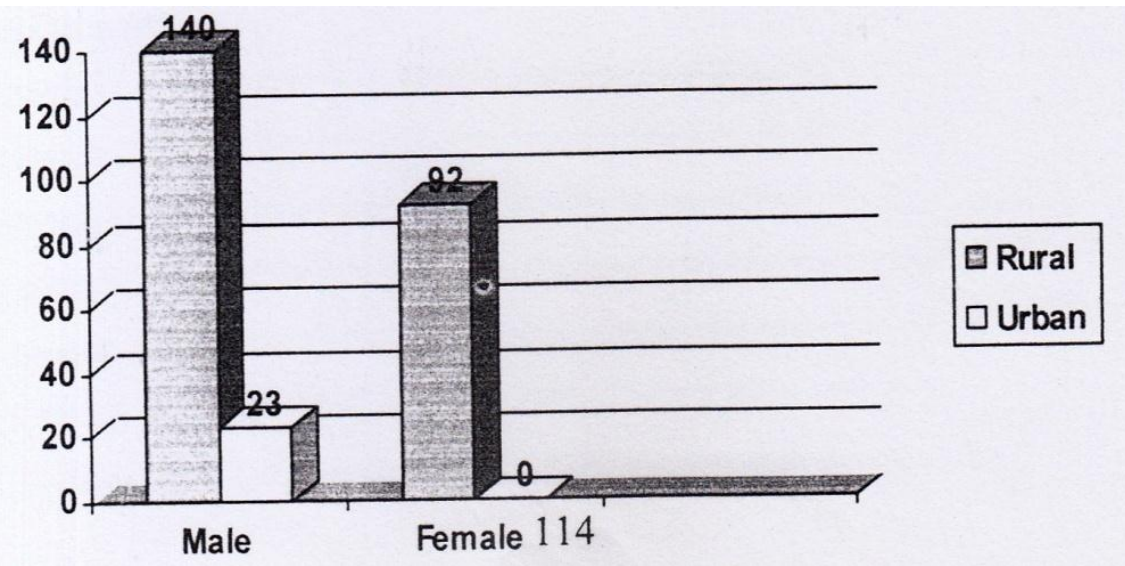

Figure 4: Average area of cultivable land by place of residence 


\section{Basic Needs, Support System And Perceived Health Problem Of The Older Population}

\subsection{Basic Needs}

As evident from socio-economic background most elderly population are poor and female elderly population are in worse situation than elderly males. All the sample elderly men and women of both rural and urban areas were asked about their basic needs. The information obtained in this respect is presented in Table In both areas and for both males and females older population's basic needs are more less the same. In rural areas $95 \%$ of the elderly males and $90 \%$ of the elderly females mentioned that their basic need is the treatment followed by cloth (75\% males and 70\% females), food (70\% males and $75 \%$ females), shelter $(35 \%$ males and $35 \%$ females) and family help (50\% males and $10 \%$ females). The pattern of needs in urban area is the same as that of the rural areas. Most respondents mentioned about treatment (95\% men and $100 \%$ women) as the most important basic needs of the older population followed by cloth (65\% and 50\%), food (60\%and 50\%), shelter (55\% and 5\%) and family help (40\% and $10 \%)$.

TABLE 8: Distributions of Respondents by Type of Basic Needs by Sex and Pace of Residence

\begin{tabular}{|l|l|l|l|l|}
\hline Type of Basic Needs & $\begin{array}{l}\text { Rural males (\%) } \\
\mathrm{N}=20\end{array}$ & $\begin{array}{l}\text { Rural Females } \\
\mathrm{N}=20\end{array}$ & $\begin{array}{l}\text { Urban } \\
\text { Males (\%) } \\
\text { N=20 }\end{array}$ & $\begin{array}{l}\text { Urban Females (\%) } \\
\mathrm{N}=20\end{array}$ \\
\hline Treatment & 95 & 90 & 95 & 100 \\
\hline Cloth & 75 & 70 & 65 & 50 \\
\hline Food & 70 & 75 & 60 & 50 \\
\hline Shelter & 35 & 35 & 55 & 5 \\
\hline Social Security & 5 & 50 & -- \\
\hline Family help & 10 & 40 & 10 \\
\hline Recreation & 50 & 40 & - & - \\
\hline
\end{tabular}

** Percentage may not add to hundred because of multiple responses

\subsection{Type of persons help in meeting the basic needs}

Types of persons help the elderly population in case of need were also obtained. The information in table shows that son is still the main source of help in the family. However, the poverty of the family. Because son must provide money for their own families first, they have little left to give to their parents. Primary responsibility for parents traditionally falls to the son who provides shelter and food. About $85 \%$ of the males and over $75 \%$ of the females from rural areas stated their son helps them in case of need. In urban area also son's help dominated with about $75 \%$ of elderly respondents mentioned that they get support from their son in case of need. The survey findings indicate that daughters are also taking responsibility their elderly parents. This is an emerging trend, but still is not the societal norm. They also received support from the neighbors and sonsin-law respectively. In urban area son helps their elderly parents followed by their daughters. The information suggests that relatives also help in the urban areas.

TABLE 9: Distribution of respondents by type of persons help in meeting the daily needs.

\begin{tabular}{|l|l|l|l|l|}
\hline Type of person help** & $\begin{array}{l}\text { Rural males (\%) } \\
\mathrm{N}=20\end{array}$ & $\begin{array}{l}\text { Rural Females } \\
\mathrm{N}=20\end{array}$ & $\begin{array}{l}\text { Urban } \\
\text { Males (\%) } \\
\text { N=20 }\end{array}$ & $\begin{array}{l}\text { Urban Females (\%) } \\
\text { N=20 }\end{array}$ \\
\hline Son & 85 & 75 & 75 & 75 \\
\hline Daughter & 15 & 15 & 20 & 15 \\
\hline Son in Law & 5 & 10 & -- & 5 \\
\hline Relatives & 5 & 15 & 5 & 10 \\
\hline Neighbors & 10 & 5 & -- \\
\hline Community & 10 & 5 & -- & -- \\
\hline Others & 5 & 15 & 20 & 20 \\
\hline
\end{tabular}

** Percentage may not add to hundred because of multiple responses

\subsection{Community support}

In Bangladesh, older population is left out of the development process and consistently lacks means to fulfill their most basic needs such as food, clothes, proper housing and health care, and also lack access to resources and income generating opportunities. All the elderly respondents were asked what their basic needs are. In response to the question they mentioned a number of basic needs.

While families remain the primary source of support, elderly population mentioned that they receive support from their communities in distress. Although community may not help them by giving cash Taka, but they receive support in the form of food, cloths and transport to medical facilities. The support systems for older men and women differ, suggesting older women's dependency on their families for survival. Older women than older men live alone and thus are dependent on their income. Old -old women are completely dependent on family and community support. In rural areas older men have social network of support than older women because of their greater mobility and they have the freedom to meet with friends in the community and 
gossiping in tea stall in the local market or roadside tea stall while women do not have such opportunities because of cultural barriers. Women are thus isolated both socially and economically, further increasing their dependency and vulnerability.

\subsection{Perceived Health Problems}

Health status of the elderly population is a major concern in Bangladesh. In Bangladesh the ratio of population and doctor is 1:13,000 i.e. one doctor for about 13000 population. Bangladesh lacks medical facilities and infrastructure to meet the needs of the vast rural population not to speak of the older population. Most elderly population expressed concern about their health as it has a direct impact on their ability to earn for their livelihood. All the sample elderly persons were asked whether they had any health problem. If they had any health problem then they were asked to state the nature of the health problem they were having at that time. The information is shown in Table it provides their health concerns and assesses their needs and explains the condition of lives. This chapter discusses basic health care needs of the elderly population; understanding about health status of the elderly population, self care practices and health seeking behavior. Health care is one of the basic needs for the survival of the elderly population in Bangladesh. The majority of elderly population in Bangladesh lives in absolute poverty. Elderly population suffers from cumulative effects of a lifetime of deprivation, entering old age in a poor state of health, and without savings or material assets. In order to obtain an understanding of health problems experienced by elderly population the survey collected detail information on the health problems in both rural and urban areas respectively. Almost every elderly population reported some health problem. There are differences in the health problem experienced by urban and rural elderly population.

TABLE 10: Distribution of self reported Health Problems reported by the Elderly People by Sex and Place of Residence

\begin{tabular}{|c|c|c|c|c|}
\hline \multirow{2}{*}{$\begin{array}{l}\text { Health problems as reported by the elderly } \\
\text { persons }\end{array}$} & \multicolumn{2}{|l|}{ Rural } & \multicolumn{2}{|c|}{ Urban } \\
\hline & Women $(\%) \mathrm{N}=20$ & $\begin{array}{c}\text { Men }(\%) \\
\mathrm{N}=20\end{array}$ & $\begin{array}{c}\text { Women }(\%) \\
\mathrm{N}=20\end{array}$ & $\begin{array}{c}\text { Men }(\%) \\
\mathrm{N}=20\end{array}$ \\
\hline $\begin{array}{l}\text { General symptoms } \\
\text { Generated Weakness } \\
\text { Sleepiness } \\
\text { Denture problem } \\
\text { Hearing problem }\end{array}$ & $\begin{array}{l}75 \\
45 \\
15 \\
25\end{array}$ & $\begin{array}{l}75 \\
45 \\
50 \\
15\end{array}$ & $\begin{array}{l}95 \\
40 \\
10 \\
10\end{array}$ & $\begin{array}{l}65 \\
25 \\
25 \\
5\end{array}$ \\
\hline $\begin{array}{l}\text { Muscular - skeletal } \\
\text { Body ache } \\
\text { Lower backache } \\
\text { Rheumatic Pain } \\
\text { Pain in joint } \\
\text { Stiffness in joint }\end{array}$ & $\begin{array}{l}80 \\
10 \\
5 \\
35 \\
20\end{array}$ & $\begin{array}{l}45 \\
20 \\
5 \\
45 \\
5\end{array}$ & $\begin{array}{l}95 \\
10 \\
60 \\
25 \\
5\end{array}$ & $\begin{array}{l}35 \\
10 \\
35 \\
5 \\
10\end{array}$ \\
\hline $\begin{array}{l}\text { Respiratory } \\
\text { Bronchial }\end{array}$ & 15 & 30 & 5 & 10 \\
\hline $\begin{array}{l}\text { Cardiovascular } \\
\text { High blood pressure }\end{array}$ & 45 & 30 & 45 & 30 \\
\hline $\begin{array}{l}\text { Gastro Intestinal Tract Infection } \\
\text { Constipation } \\
\text { Dysentery }\end{array}$ & $\begin{array}{l}10 \\
15\end{array}$ & $\begin{array}{l}35 \\
15\end{array}$ & $\begin{array}{l}10 \\
10\end{array}$ & $\begin{array}{l}15 \\
15\end{array}$ \\
\hline $\begin{array}{l}\text { Eye } \\
\text { Vision problem } \\
\text { Mental Problem } \\
\text { End chronic disease } \\
* \text { Diabetics }\end{array}$ & $\begin{array}{l}65 \\
10 \\
10 \\
5\end{array}$ & $\begin{array}{l}70 \\
15 \\
10 \\
5\end{array}$ & $\begin{array}{l}75 \\
10 \\
5 \\
5\end{array}$ & $\begin{array}{l}55 \\
15 \\
10 \\
5\end{array}$ \\
\hline $\begin{array}{l}\text { Nervous System } \\
\text { Paralysis } \\
\text { Difficult in moving }\end{array}$ & 10 & 10 & 15 & 10 \\
\hline $\begin{array}{l}\text { Dementia } \\
\text { Others (Hernia, Disability, Leg Swollen, } \\
\text { Allergy, Social Isolation, Leprosy) }\end{array}$ & $\begin{array}{l}5 \\
20\end{array}$ & $\begin{array}{l}5 \\
20\end{array}$ & $\begin{array}{l}5 \\
40\end{array}$ & $\begin{array}{l}5 \\
30\end{array}$ \\
\hline
\end{tabular}

** Percentage may not add to hundred because of multiple response.

\subsection{Whether suffered from any disease during the three months preceding the survey}

Every respondent irrespective of sex and place of residence suffered from a disease during three moths preceding the survey. In the both areas majority of the elderly population suffered from weakness $(75 \%$ and $75 \%$ ) followed by eye sight (95\% and 65\%), sleeping problem (45\% and $45 \%$ ), Blood pressure (40\% and 25\%) body pain $(80 \%$ and $45 \%)$ and pin in joint $(95 \%$ and $35 \%)$. in rural areas more elderly population suffers from eyesight, hearing and denture, weakness, sleepless, mobility, blood pressure, stiff joint, constipation, pain in join in back rheumatic. 


\subsection{Type of from whom received support}

Among the respondents who reported physical disability were asked who support in looking after them in respect of taking them toilet, bath etc. the information suggests that in most instances wife provided support to elderly men. The other important support comes from the daughters in law, Grandchildren. In case of taking to health facility visit son's support is significant.

\subsection{Whether suffered from any disease during the last three months?}

All the sample elderly population was asked whether they suffered any disease during the last three months prior to the survey. The information obtained is presented in Table. In general more rural older population suffered from diseases than older population from urban area. Similarly older women suffered from illness than their male counterparts. Roughly three fourths of the elderly population (older men and women) in rural areas suffered from diseases during the last three months prior to the survey. The comparable figures in urban areas were $40 \%$ and $30 \%$ respectively.

TABLE 11: Percent distribution of Elderly Population by whether suffered any Disease during the last three months preceding survey by sex and place of residence.

\begin{tabular}{|l|l|l|l|l|}
\hline $\begin{array}{l}\text { Whether suffered from any } \\
\text { disease }\end{array}$ & $\begin{array}{l}\text { Rural males (\%) } \\
\mathrm{N}=20\end{array}$ & $\begin{array}{l}\text { Rural Females } \\
\mathrm{N}=20\end{array}$ & $\begin{array}{l}\text { Urban } \\
\text { Males }(\%) \\
\mathrm{N}=20\end{array}$ & $\begin{array}{l}\text { Urban Females (\%) } \\
\mathrm{N}=20\end{array}$ \\
\hline Yes & 70 & 75 & 60 & 70 \\
\hline No & 30 & 25 & 40 & 30 \\
\hline
\end{tabular}

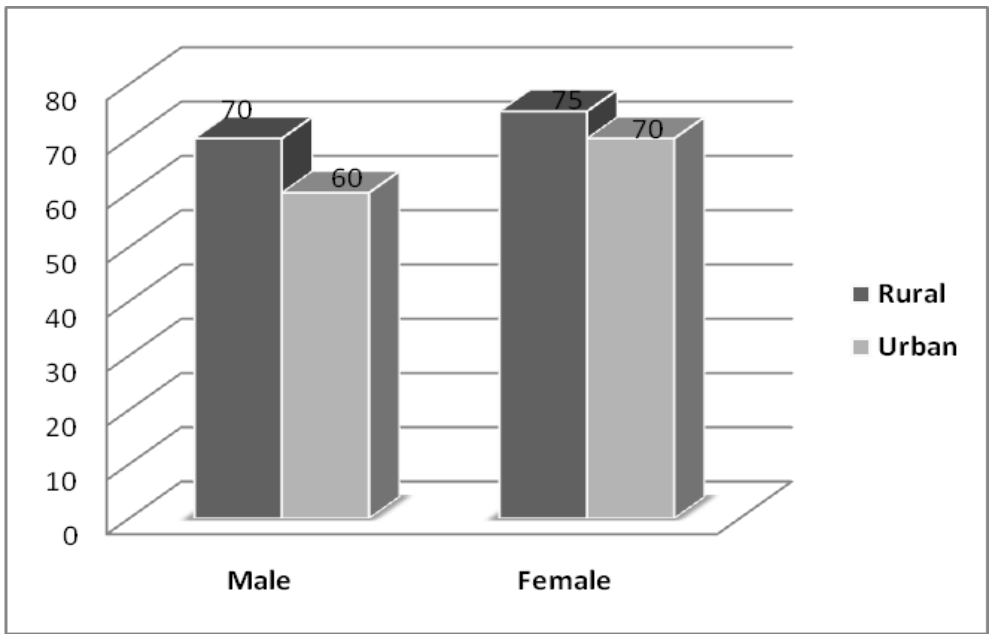

Figure 5: Distribution of respondents suffered from disease during last three months preceding the survey by sex and place of residence.

\subsection{Type of diseases suffered}

The elderly respondents who reported that they suffered from diseases during the last three months prior to the survey were asked to mention the diseases they suffered Table. The most frequently stated disease men and women suffered from were gastrointestinal, respiratory infection cardio vascular nervous system and fever. The information also suggests that more men suffered from rheumatic fever than that of women.

\subsection{Whether Received Treatment and Place of Treatment}

The older men and women who reported they suffered from disease were asked whether visited. Any health facility for treatment. In rural areas about $90 \%$ of the respondents they visited health facility for treatment. The corresponding percent of older men visited health facility in urban area was about $80 \%$ for women respectively. The older women who stated they visited health facility for treatment were again asked to specify about the type of person provided treatment. A majority of older women and men visited NGO clinic for treatment. For example, in rural area more about $16 \%$ older men visited NGO clinic for treatment as opposed to about $30 \%$ of the older women in rural area more older women than older women visited private clinic for treatment $(22.22 \%$ men and $11.11 \%$ women). But in urban area percentage of older men who received treatment from private clinic was considerable higher than that of older women (50\% as against $23 \%$ ). In rural area about one in five respondents mentioned they visited village doctor for treatment. The comparable figures were much lower in the urban area with only $6 \%$ and $5 \%$ stated that they visited village doctor for treatment. As expected hospital visit by the older men for treatment was higher in the urban area than that of older women. 
Social Status Of Elderly People In Health Perspective: A Comparison Of Rural And Urban Area

TABLE 12: Distribution Elderly Respondents by whether Received Treatment and place of Treatment by Sex and Place of Residence.

\begin{tabular}{|l|l|l|l|l|}
\hline $\begin{array}{l}\text { Whether Received } \\
\text { Treatment }\end{array}$ & $\begin{array}{l}\text { Rural males (\%) } \\
\mathrm{N}=20\end{array}$ & $\begin{array}{l}\text { Rural Females } \\
\mathrm{N}=20\end{array}$ & $\begin{array}{l}\text { Urban } \\
\text { Males (\%) N=20 }\end{array}$ & $\begin{array}{l}\text { Urban Females (\%) } \\
\mathrm{N}=20\end{array}$ \\
\hline Yes & 90 & 90 & 80 & 85 \\
\hline No & 10 & 10 & 20 & 15 \\
\hline Type of person visited for treatment & 11.11 & 16.67 & 6.25 & 5.88 \\
\hline Village Doctor & 5.56 & 16.67 & 12.5 & 23.53 \\
\hline Hospital & 16.67 & 30.89 & 31.25 & 41.18 \\
\hline NGO clinic & 22.22 & 11.11 & 50 & 23.53 \\
\hline Privet clinic & 22.22 & 5.556 & -- & 5.88 \\
\hline Kabiraj & 22.22 & 11.11 & -- & - \\
\hline Homeopath & & & \\
\hline
\end{tabular}

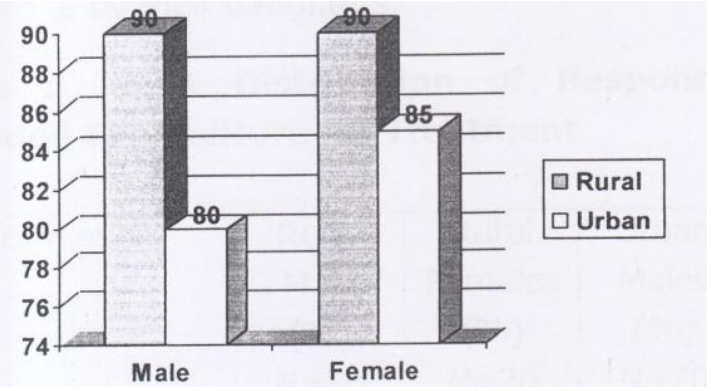

Figure 6: Distribution of respondents who received treatment for disease by sex and place of residence

\subsection{Expenditure on health care and who provided the expenditure}

Treatment costs money and therefore health care expenditure is an important determinant to receive health care services. The elderly men and women who suffered from different diseases and who reported to have received treatment were asked about expenditure on treatment. The average expenditure of male elderly population was much higher than their counter parts. For instance, the average amount of expenditure for treatment of male elderly population was Taking 1846 as oppto only 583 Taka by elderly women. The reverse was true for urban area. Expenditure on treatment by female elderly population however, this information on information and also tendency by the respondents to exaggerate the expenditure. Table gives the type of relatives who bore the expenditure of treatment very often. 55\% and $45 \%$ of older men and women reported that their son bore the expenditure of treatment. In urban area more older women than men (45\% vs. 55\%) mentioned that their son bore the expenditure on treatment. Daughter supported older women than men. In urban area one in four older women mentioned their treatment expenditure was borne by daughters.

TABLE 13: Distribution of Respondents who provided Expenditure for Treatment

\begin{tabular}{|l|l|l|l|l|}
\hline $\begin{array}{l}\text { Type of } \\
\text { Person }\end{array}$ & $\begin{array}{l}\text { Rural males (\%) } \\
\mathrm{N}=20\end{array}$ & $\begin{array}{l}\text { Rural Females } \\
\mathrm{N}=20\end{array}$ & $\begin{array}{l}\text { Urban } \\
\text { Males (\%) } \\
\text { N=20 }\end{array}$ & $\begin{array}{l}\text { Urban } \\
(\%) \\
\mathrm{N}=20\end{array}$ \\
\hline Son & 55 & 45 & 45 & 55 \\
\hline Daughter & 5 & 10 & 10 & 25 \\
\hline Relatives & 5 & 10 & 5 & 5 \\
\hline Self & 30 & 15 & 40 & 10 \\
\hline Others & 5 & 10 & -- & 5 \\
\hline
\end{tabular}

\subsection{Distance of the health facility from the residence}

Distance of the health Center is also an important factor whether or not to visit health facility for treatment. The respondents perceived this distance. This may not be consistent with reality. In rural area average distance perceived by order women was higher than that of older men (1.3 kilometers vs. 1.5 kilometers). Similar pattern is found in urban area. In urban area older women reported that average distance of health facility from the residence was about one kilometer compared to 0.7 kilometers by the older men.

\subsection{What are the activities NGO should do?}

All the elderly population was asked to opine what NGOs should do for the welfare of the elderly population. The elderly population from both areas gave a number of suggestions that should be implemented for the welfare of the elderly population. The information is shown in Table. The elderly population gave a number of suggestions, which NGOs should do for the welfare of the elderly population. These included: availability of low cost medicine, free of cost medicine, free access to health care service, income generation activities and counseling on health care. 
TABLE 14: Distribution Elderly Populations by Activities of NGOs

\begin{tabular}{|l|l|l|}
\hline Type of Activity & $\begin{array}{l}\text { Rural } \\
(\mathrm{M}+\mathrm{F}) \\
(\%) \\
\mathrm{N}=40\end{array}$ & $\begin{array}{l}\text { Urban } \\
(\mathrm{M}+\mathrm{F}) \\
(\%) \\
\mathrm{N}=40\end{array}$ \\
\hline Low cost Medicine & 15 & 5 \\
\hline Pre Medicine & 12.5 & 5 \\
\hline Health care facilities & 45 & 57.5 \\
\hline Free treatment & 7.5 & 5 \\
\hline Shelter & 2.5 & -- \\
\hline Economic activities & 67.5 & 57.5 \\
\hline Counseling on health & 15 & 17.5 \\
\hline Support in treatment & 5 & -- \\
\hline Health services near by residence & 2.5 & -- \\
\hline Sufficient security & 7.5 & - \\
\hline Other & 5 & -- \\
\hline
\end{tabular}

** Percentage may not add to 100 percent because of multiple responses.

\subsection{Suggestions for Welfare of the Elderly Population in their Locality}

All the elderly population was asked to opine about type of activities should be under taken for the welfare of the elderly population in their locality. The information was collected separately for both men and women elderly population. Tables show the suggestions provided by the respondents separately for female and male elderly population. Both elderly men and women suggested availability of medicine in medicine, location of health care near to the residence and health care by health workers for elderly women. The pattern is the same for urban area. More or less similar suggestions were provided for male elderly population. The respondents also suggested good doctor, food security and supply of food for the male elderly population.

TABLE 15: Distributions of Elderly by their Suggestions for Welfare of the Elderly Females

\begin{tabular}{|l|l|l|}
\hline Suggestions for the welfare females elderly & $\begin{array}{l}\text { Rural } \\
(\%) \\
\mathrm{N}=20\end{array}$ & $\begin{array}{l}\text { Urban } \\
(\%) \\
\mathrm{N}=20\end{array}$ \\
\hline Reduction in medicine cost & 40 & 30 \\
\hline Free treatment & 30 & 45 \\
\hline Good behavior health care providers & 5 & 5 \\
\hline Affordable treatment & 5 & 5 \\
\hline Availability of treatment in cheap & 25 & 10 \\
\hline Treatment & 5 & 5 \\
\hline Availability of medicines & 5 & -- \\
\hline Health care near to the residence & 25 & 10 \\
\hline Good medicine & 20 & 30 \\
\hline Home care by the health workers & 10 & 15 \\
\hline Others & 15 & 5 \\
\hline
\end{tabular}

** Percentage may not add to hundred because of multiple response.

Table 16: Distributions of Elderly by their Suggestions for Welfare of the Elderly Males

\begin{tabular}{|l|l|l|}
\hline Suggestions for the welfare elderly males & $\begin{array}{l}\text { Rural } \\
(\%) \\
\mathrm{N}=20\end{array}$ & $\begin{array}{l}\text { Urban } \\
(\%) \\
\mathrm{N}=20\end{array}$ \\
\hline Medicine at reduced cost & 50 & 30 \\
\hline Free treatment & 30 & 55 \\
\hline Good behavior health of providers & 5 & 5 \\
\hline Affordable treatment & 5 & 5 \\
\hline Availability of treatment in cheap & 30 & 10 \\
\hline Availability of sufficient medicines & 25 & 5 \\
\hline Health care services near to the residence & 20 & 35 \\
\hline Good doctor & 15 & 25 \\
\hline Food security & 5 & -- \\
\hline Supply of good food & $5 * 2$ & -- \\
\hline \multicolumn{2}{|l}{} \\
\hline
\end{tabular}

Current and future health needs of older people should be urgently addressed through promotion of health education and information targeting older population. Introduction of medical card in the hospital and health center would be an important step in this respect. It is recommended that health workers should visit elderly men and women and should take them to health them to health center particularly those who are physically weak and unable to move long distance. A day in the week should be fixed in all the government hospitals for the elderly population so that they can see the doctors easily. All the elderly persons should get the 
services free of cost. The health care plans that need to be addressed for the vast elderly population over the next few years will influence the well being of the elderly population in Bangladesh. If feasible and possible treatment services for the elderly who cannot move should be provided through mobile hospital. Government / NGO development programs should give priority to those son

\section{Conclusion}

The majority of older people in Bangladesh are living in absolute poverty. The present report highlights poor older people's basic needs; how they survive and the contributions they make to the family. The survey findings indicate that elderly men and women lack access to land and agricultural resources. Access to resources, and therefore livelihood strategies, have changed for both older men and women. Most of the elderly populations are landless and they earn very little from land. The findings from the study show that poor older people in rural areas faces very difficult circumstances as they attempt to meet their basic needs. Many elderly persons have only homestead land but no agricultural land. Again, some elderly persons even do not have homestead land.

The health status of elderly population is poor and they lack access to basic health care and sanitation facilities. About 80 percent of the elderly population suffered from health problems. Almost every one suffered from at least one disease during three months prior to the survey. The average duration of suffering from diseases ranged from 3 years to 9 years. The vibration analysis shows that age, sex, access to treatment and income is associated with the health problems of the older population. Similarly, logistic regression analysis suggests that age; landholding education and sex of the respondents are determinants of duration of health problems.

National policies need to incorporate the issue of aging and appropriate support mechanisms for older people into the mainstream of their social, economic and health planning. Creation of special geriatric wards in major hospitals, setting up of special counters and geriatric outpatients units in Social gerontology needs to be form a part of the medical professionals. Community members have to be sensitized about the problems of the elderly so that a greater commitment and Involvement could be ensured to include care for the elderly within health care system. Many diseases and illness of later life are the consequence of earlier behavior. Developing healthy lifestyles and environments for all ages will mean fewer problems for future aged population.

Considering the size of the elderly and their dimension of problems the Health Ministry and the Ministry of Social Welfare should establish a separate cell to deal with the provide emphasis for the promotion of health of the elderly population. The health policy should also consider separately for the elderly population. A large number of NGOs are working in Bangladesh but they do not have any program targeting the elderly population. Government should encourage the NGOs to take activities for the welfare of the elderly population. The elderly persons, who have skill in cottage industries and handicrafts, NGOs, should create opportunity for them for their better livelihood. In addition, they should under take different welfare programs for the elderly population.

\section{References}

[1] Rao, et al., Health Status of the Rural Aged in Andhra Pradesh; A Sociological Perspective in Help Age India - Research \& Development Journal, 2003,Vol.9, No. 2.

[2] Singh S.N., Nair, P.S., , M.K., Premi, P.S., Bhatia and Ashish B., The Aged in Rural India; A Study of the Socio-Economic and Health Profile in Population Transition in India, vol.2, B.R. Publishing, Delhi.

[3] Achir, Y.C., Stragegies to Formulate Family Suppoert Systems and Community based Servicves for the Care of the Old in Technical Reports Series Monograph, 1998, No. 93. pp.26.

[4] Pappathi, K. and Sudhir, M.A., Psycho-social Characteristics and Problems of the Rural Aged in Research and Development Journal, Help Age India, 2005, Vol. 11, No. 1.

[5] Vasantha and Premakumar., Nutrition and Health Problems of Aged, Paper presented at National Seminar on Psycho-social Characteristics, Problems and Strategies for the Welfare of the Aged in Rural India, Department of Applied Research, Gandhigram Rural Institute, 1998, March 11-13, 1998.

[6] Nair, T.K., Community care of the elderly - A study of family and community based services in Madras in Unpublished Doctoral Thesis, 1991, Andhra University, Visakhapatnam.

[7] Balamurugan J. and G. Ramathirtham., "Health Problems of Aged People" IJRSS, 2012, Volume 2, Issue 3, ISSN: $2249-2496$ Ibrahim, M., "Problems of the Aged In Bangladesh", paper presented at the Symposium on Population Development and Social Security: Aging in Developing Countries, 1981, Hamburg, Federal Republic of Germany.

[8] Mustafa, G., Streatfield K., Health Implication of an Ageing Bangladeshi Population. ICDDR, B. Dhaka. 2002.

[9] Kalam I. M. S. and Khan T. A. H, 2006, “Morbidity Among Older People in Bangladesh: Evidance from Ageing Survey” BRAC University Journal, vol. III, no.2, 2006, pp. 75-83

[10] Wrosch C., Schulz R., Miller G. E., Lupien S. and Dunne E., "Physical Health Problems, Depressive Mood, and Cortisol Secretion in Old Age: Buffer Effects of Health Engagement Control Strategies" Health Psychology, Copyright 2007 by the American Psychological Association, 2007, Vol. 26, No. 3, 341-349 0278-6133/07/\$12.00 DOI: 10.1037/0278-6133.26.3.341 